\author{
SUMMARY \\ COMPARISON OF THREE, CERFALS : WHEAT, MAIZE, BARLEY \\ AND MAIZE-BARLEY, MAIZE-WHEAT MIXTURES \\ IN GROWING-FINISHING PIG DIETS
}

The purpose of our experiment was to compare the feeding value of maize, wheat and barley and of maize-wheat, maize-barley mixtures (at two levels : $2 / 3-1 / 3-1 / 3-2 / 3$ ) in the rations of growing-finishing pigs from 25 to $103 \mathrm{~kg}$ live weight.

The diets were prepared so as to maintain a constant ratio between digestible energy and protein (20 kcal/g protein).

The wet feed was given in two daily meals. The animals were subjected to restricted feeding after a period of semi ad libitum feeding. The restriction levels were calculated so that the animals received 8 roo kcal of digestible energy, $415 \mathrm{~g}$ crude protein and $23 \mathrm{~g}$ lysine during the finishing period.

For the whole growing-finishing period, the energy and protein efficiencies were comparable whatever the cereal or cereal mixture used. The food conversion ratios, expressed in amount of food necessary for $\mathbf{I} \mathrm{kg}$ weight gain, were closely correlated with the energy concentration of the diets. They increased from 3.Io to 3.50 when the concentration decreased from $3400 \mathrm{kcal}$, digestible energy (diets based on maize and barley, respectively), to 3 ooo kcal digestible energy.

\title{
VAIEUR d'Utilisation de maïs SÉchés EN DEUX Passages OU AVEC REFROIDISSEMENT LENT DIFFÉRE
}

\author{
J. MOAL et J. CASTAING \\ Association générale des Producteurs de Mais, \\ 1, Place Lestapis, \\ 64000 Pau

\section{RÉSUMÉ}

Pour augmenter le débit de réception des séchoirs en période de récolte, il est possible de sécher les maïs jusqu'à $20 \mathrm{p}$. Ioo d'humidité environ, de les stocker sans refroidissement, puis de les sécher définitivement en cellule (refroidissement différé). Il est possible également de les sécher provisoirement jusqu'à 25 p. Ioo d'humidité et de les maintenir sous ventilation en attendant un séchage définitif (séchage en deux passages).

Deux expériences semblables (une par méthode de séchage) d'alimentation de porcs charcutiers, de 25 à $103 \mathrm{~kg}$ vifs, ont été menées de façon à apprécier ces méthodes par rapport à un séchage classique en un seul passage avec de l'air à $90^{\circ} \mathrm{C}$ et, pour le séchage en deux temps, par rapport également à un séchage en épis avec de l'air à $40^{\circ} \mathrm{C}$ (séchage de type "semences "). Les expériences ne mettent en évidence aucune différence entre les deux facteurs principaux de l'essai : 
- les méthodes de séchage conduisent à des résultats analogues, contrairement à une expérience précédente laissant entenđre que le séchage en deux temps, notamment, préservait mieux l'intégrité du grain de maïs ;

- les températures de séchage, allant de 90 à $150^{\circ} \mathrm{C}$ pour les deux méthodes à l'essai, sont également sans influence sur les résultats des essais.

\author{
SUMMARY \\ FEEDING VALUE OF MAIZE SUBJECTED TO DIFFERENT \\ DRYING TREATMENTS : TWO-STAGES DRYING OR DRYING \\ FOLLOWED BY DEI,AYED SLOW COOLING
}

In order to increase the reception rate of dryers during the period of harvesting, it is possible either to dry the maize till about $20 \mathrm{p}$. Ioo humidity, followed by storage without cooling and drying in a bin (delayed cooling), or to dry the maize provisionally till $25 \mathrm{p}$. Ioo humidity, followed by ventilation until the definitive drying (two-stages drying).

Two similar experiments (one per drying method) dealing with feeding of growing-finishing pigs from 25 to $103 \mathrm{~kg}$ live weight were made. The purpose was to compare these two methods with the classical one-stage drying at $90^{\circ} \mathrm{C}$ and in the case of two-stages drying, comparison was also made with drying at $4 \mathrm{O}^{\circ} \mathrm{C}$ according to the "herring-bone " system. The experiments did not show any difference between the two main factors of the trial :

- the drying methods gave analogous results contrarily to a previous trial, which indicated that two-stages drying, in particular, resulted in a better preservation of the integrity of the kernel ;

- the drying temperatures $\left(90\right.$ to $150^{\circ} \mathrm{C}$ ) of the two methods studied did not affect the results of the experiments.

\title{
ESSAI D'UTILISATION DE FORTES PROPORTIONS DE MÉlaSSE DE CANNE A SUCRE DANS LES RATIONS DU POHCELET SEVRÉ A 5 SEMAINES ET DU PORC EN CROISSANCE-FINITION
}

\author{
J. LE DIVIDICH, B. SEVE, I. CANOPE et H. KEMPF \\ Station de Recherches sur l'Élevage des Porcs, \\ Centre national de Recherches zootechniques, I. N. R. A., \\ 78350 Jouy en Josas \\ Station de Recherches zootechniques, \\ Centre de Recherches agronomiques des Antilles-Guyane, I. N.R. A., \\ Domaine Duclos, 97170 Petit Bourg (Guadeloupe)
}

\section{RÉSUMÉ}

Trois essais ont été réalisés afin de connaître :

$I^{\circ}$ L'effet d'une incorporation importante (o à $40 \mathrm{p}$. 10o) de mélasse finale de canne dans les régimes de sevrage sur les performances du porcelet entre 5 et 9 semaines d’âge. 